Solid oxide structure of the cobalt-free composite has been exploited as a new cathode material for IT-SOFCs. The composite model system was synthesized using the metallic oxide material, which was formed by a solid-state reaction technique. The generation of the $\mathrm{Sm}_{0.5} \mathrm{Sr}_{0.25} \mathrm{Ba}_{0.25} \mathrm{FeO}_{3-\delta} \quad$ (SSBF) model system was carried out during the sintering process. The weight loss and oxygen content were investigated by thermal gravimetric analysis (TG). Meanzhile, $X$-ray diffraction characterized the structure of the composite and thermal conductivity tested the conductivity properties. The results showed that the structure of the SSBF composite demonstrated the perovskite single phase leading to the structural design. The decomposition and evaporation of the constituent elements of the composite corresponded to weight losses during the constructing process. The oxygen content of the model system was 2.98 after the calcination process. The electrical conductivity value reached $2 \mathrm{~S} \mathrm{~cm}^{-1}$ at $400{ }^{\circ} \mathrm{C}$ and increases to a maximum of $7.5 \mathrm{~S} \mathrm{~cm}^{-1}$ at $710^{\circ} \mathrm{C}$. The metallic element played to generating the conductive behavior at the low temperature, while the ionic structure acted as elevated temperature. So, mixed ionic and electric conductors (MIEC) were employed comprehensively for creating the conductive properties. Based on the structure and conductivity results, the SSBF composite has a good chance as an alternative cathode material with a perovskite single phase for future TI-SOFCs applications Keyzords: solid oxide fuel cells, cobalt-free cathode composite, perovskite structure, oxygen content, conductivity
UDC 621

DOI: $10.15587 / 1729-4061.2021 .239162$

\section{DESIGN OF SOLID OXIDE STRUCTURE ON THE COMPOSITE CATHODE FOR IT-SOFC}

\author{
Dianta Mustofa Kamal \\ Doctor of Energy Conversion, Assistance Professor* \\ I wan S u santo \\ Corresponding author \\ Doctor of Materials Science and Engineering, Assistance Professor* \\ E-mail: iwan.susanto@mesin.pnj.ac.id \\ Rah mat S ubarkah \\ Master of Thermo Fluids Engineering, Assistance Professor* \\ Fu ad Z a in u ri \\ Doctoral Candidate of Mechanical Engineering, Assistance Professor*
}

B e l y a m in

Doctor of Energy Conversion, Assistance Professor*

Tia Rahmiati

Master of Engineering in Metallurgy and Materials, Assistance Professor*

Sulaksana Permana

Doctor of Engineering in Metallurgy and Materials, Assistance Professor

Centre of Mineral Processing and Corrosion Research

Department of Metallurgy and Materials

Universitas Indonesia

Jl. Margonda Raya, Pondok Cina, Kecamatan Beji, Kota Depok, Jawa Barat, Indonesia, 16424

Adi Subardi

Doctor of Materials Science and Engineering, Assistance Professor Department of Mechanical Engineering Institut Teknologi Nasional Yogyakarta

J. Babarsari, Tambak Bayan, Caturtunggal, Kec. Depok, Kabupaten Sleman, Daerah Istimewa Yogyakarta, Indonesia, 55281

Y e n-Pei F u

Doctor of Materials, Professor

Department of Materials Science and Engineering

National Dong Hwa University

Shoufeng Township, Hualien, Taiwan ROC, 97401

*Department of Mechanical Engineering Politeknik Negeri Jakarta

JI. Prof. DR. G.A. Siwabessy, Kukusan, Kecamatan Beji, Kota Depok, Jawa Barat, Indonesia, 16424
How to Cite: Kamal, D. M., Susanto, I., Subarkah, R., Zainuri F., Belyamin, Rahmiati, T., Permana, S., Subardi, A., Fu, Y.-P. (2021). Design of solid oxide structure on the composite cathode for it-sofc. Eastern-European Journal of Enterprise Technologies, 4 (5 (112)), 6-11. doi:https://doi.org/10.15587/1729-4061.2021.239162

\section{Introduction}

A solid oxide fuel cell (SOFC) is an electrochemical device developed continuously due to its high performance, low environmental effects and fuel flexibility for generating electricity [1]. The device is applied extensively to be used for future commercial purposes, which makes it easy to implement in a wide range of applications. The use of this 
technology has been developed for both the energy efficiency building [2], and the satisfying of economics evaluation for residential power system [3]. Moreover, it has also been supported for fuel cell electric vehicles as a power plant with an efficiency increase of up to $20 \%$ in SOFC-reformer by reducing energy destruction [4]. However, SOFC currently operates at high temperatures $\left(800-1,000{ }^{\circ} \mathrm{C}\right)[5]$. Its temperatures limit material choices for cells and auxiliary components, increase the degradation of cell performance and interconnecting elements between components, and increase the difficulty of sealing. Some critical technical problems, especially those related to reliability and durability, need to be resolved to move technology to commercialization.

Mixed ionic and electric conductors (MIEC) are widely promoted in intermediate temperature solid oxide fuel cells (IT-SOFCs) made of perovskite-type oxides, which are symbolized by ABO3- $\delta[6]$. They are suitable for a variety of uses, including electrocatalysts for solid oxide fuel cells (SOFCs), oxygen-permeable membranes, and oxygen absorbers. MIEC cathode has been stated to have good electrocatalytic activities, excellent oxygen transport and surface exchange properties, and hence high electrochemical activities in some experiments [7,8]. However, in practice for long-term applications, these cobalt-based MIECs have poor stability due to the high thermal expansion of the electrolyte, which has hampered the development of IT-SOFC cathodes [9]. Furthermore, the high cost of cobalt (Co) in comparison to other rare metals is another factor to remember for successful use [10]. To address the numerous limitations mentioned above, the analysis is needed to discover a novel composite structure of cobalt-free cathode material for intermediate-temperature solid oxide fuel cells (IT-SOFCs).

\section{Literature review and problem statement}

Up to now, there has been a lot of studies on Co-free cathodes as a way to overcome the problems in the implementation of IT-SOFCs [11]. So, the development of a new model of cobalt-free cathode was carried out [12]. MIEC model with Fe in the B-side on the composite structure of the cathode system as Fe-based composite oxides is expected to be low-cost and more durable under SOFC operation conditions (500 to $800{ }^{\circ} \mathrm{C}$ and air atmosphere) due to the strong electronic structure of Fe ions [13, 14]. The composite model has been continually evolved in the A-side-based perovskite oxides in order to achieve excellent cathode performance up to now. Using the metal transition to strengthen the perovskite structure on the A-side has received a lot of attention [15, 16]. Barium (Ba) is one of the famous elements that is applied in the A-side of the composite structure as a BLF system for the cathode element $[17,18]$. The excellent structure is related to the electro-catalytic activities for oxygen reduction, as well as the good operational stability. Furthermore, the substitution of samarium (Sm), Ba and Samarium (Sr) elements in the A-site shows the great performance of the cathode element $[19,20]$. The development of its composite has not been complete as a composite using Fe ions in the B-site. The investigation of the structure into a cobalt-free cathode employing Ba combined with Sm and $\mathrm{Sr}$ in the A-site and Fe ions in the B-side of a composite structure was rare.

\section{The aim and objectives of the study}

The aim of the study is to design a solid oxide structure on the composite cathode for IT-SOFCs. This would make it possible to determine the calcination temperature related to weight loss, constructing the perovskite structure, and improving both oxygen content and conductive properties of the SSBF composite.

To achieve this aim, the following objectives are accomplished:

- to analyze the thermal gravimetry of the composite metallic oxide;

- to characterize the structure of the composite model;

- to test the conductivity properties of the cobalt-free cathode.

\section{Materials and experimental methods}

This work investigated the structure and properties of a cobalt-free cathode based on $\mathrm{Sm}, \mathrm{Sr}, \mathrm{Ba}$, and Fe composite materials as a candidate for possible use in the cathode element of IT-SOFCs. The solid-state reaction method was employed to modify the perovskite structure using the composite of $\mathrm{Sm}, \mathrm{Sr}$ and Ba elements into the A-side, resulting in a composite cathode of the SSBF system. Characterization will also be carried out in order to learn more about the cathode model related to the structure and conductivity properties.

The raw materials used as a composite are metallic oxide compounds, namely $\mathrm{Sm}_{2} \mathrm{O}_{3}, \mathrm{SrCO}_{3}, \mathrm{BaO}$ and $\mathrm{Fe}_{2} \mathrm{O}_{3}$ (SSBF model). The solid-state reaction method is used to make the SSBF cathodes in the traditional way. The method was used for preparing the cathode material, which has been reported in our group's previous papers [21-23]. Using zirconia balls, a stoichiometric volume of metallic oxide compounds was mixed in the presence of ethanol $96 \%$ in solution for 12 hours. The powders blend was then dried in an oven at $80{ }^{\circ} \mathrm{C}$ for 24 hours. The SSBF precursor powders were calcined at $1000^{\circ} \mathrm{C}$ for 4 hours in an air atmosphere with a heating rate of $3{ }^{\circ} \mathrm{C} \mathrm{min}-1$ and normal cooling in the furnace. The calcination powder was sieved through the 400 mesh after being ground using an agate mortar. The powders were tested by thermal gravimetric (TG) analysis for checking the oxygen content. The temperature was raised up to $900{ }^{\circ} \mathrm{C}$ with a heating rate of $10{ }^{\circ} \mathrm{C} \mathrm{min}^{-1}$ and cooled to room temperature. While other powders were then pressed into a square bulk measuring $5 \times 7 \times 10 \mathrm{~mm}$. The cathode bulk was sintered for 4 hours at $1200{ }^{\circ} \mathrm{C}$ with a heating rate of $3{ }^{\circ} \mathrm{C} \mathrm{min}{ }^{-1}$ and natural cooling in the furnace. Further, the XRD was used to determine the crystal structure of the cathode powder, and the electrical conductivity bulk samples were determined from $200{ }^{\circ} \mathrm{C}$ to $800{ }^{\circ} \mathrm{C}$.

\section{Research results on the design of solid oxide structure on the composite cathode for IT-SOFC}

\section{1. Thermal gravimetric analysis}

What do you try to find in this analysis, if as you wrote "The SSBF precursor powders were calcined at $1,000{ }^{\circ} \mathrm{C}$ " and "The bulk was sintered for 4 hours at $1200^{\circ} \mathrm{C}$ with a heating rate of $3{ }^{\circ} \mathrm{C} \mathrm{min}{ }^{-1}$ and natural cooling in the 
furnace". All the interesting data was lost due to your previous step.

Fig. 1 shows the thermal gravimetric analysis and differential thermal analysis (DTA) of SSBF composite oxide powders. The blue curve from number 1 to 5 is related to the TG value of the SSBF composite, while the black curve with the point of $\mathrm{A}, \mathrm{B}$ and $\mathrm{C}$ corresponds to the thermal behavior during the calcination process. The thermal gravimetric analysis was used to monitor the weight loss of the material due to either evaporation or decomposition reaction. This method can be employed to determine the next step of calcination and sintering temperature. Based on the curve, the numbers 2 and 3 are associated with a reduction of the sample weight due to the evaporation of $\mathrm{H}_{2} \mathrm{O}$ and some impurities of the materials. While the points 4 to 5 are related to a decrease in weight due to the compound decomposition reaction.

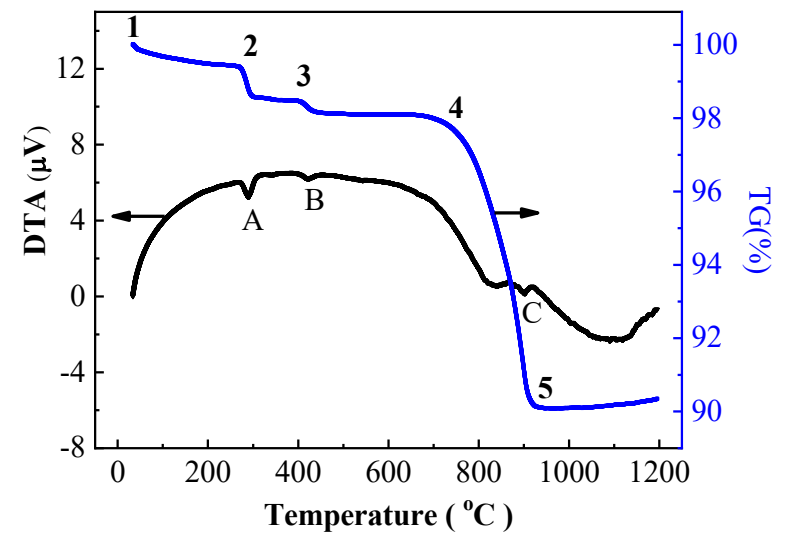

Fig. 1. Thermal gravimetric analysis (TG) and differential thermal analysis (DTA) of precursor SSBF powders

The DTA and TG curves of SSBF oxide powder heated from room temperature to $1,200{ }^{\circ} \mathrm{C}$ are shown in Fig. 1. For points $\mathrm{A}, \mathrm{B}$, and $\mathrm{C}$ of DTA, there are three steep valleys on the curve: $289^{\circ} \mathrm{C}, 422^{\circ} \mathrm{C}$, and $899^{\circ} \mathrm{C}$. In the same way that the TG curve was formed, the decreasing curve was also created in the same spot.

Fig. 2 demonstrates the TG analysis of the composite structure of the model system after the calcination process.

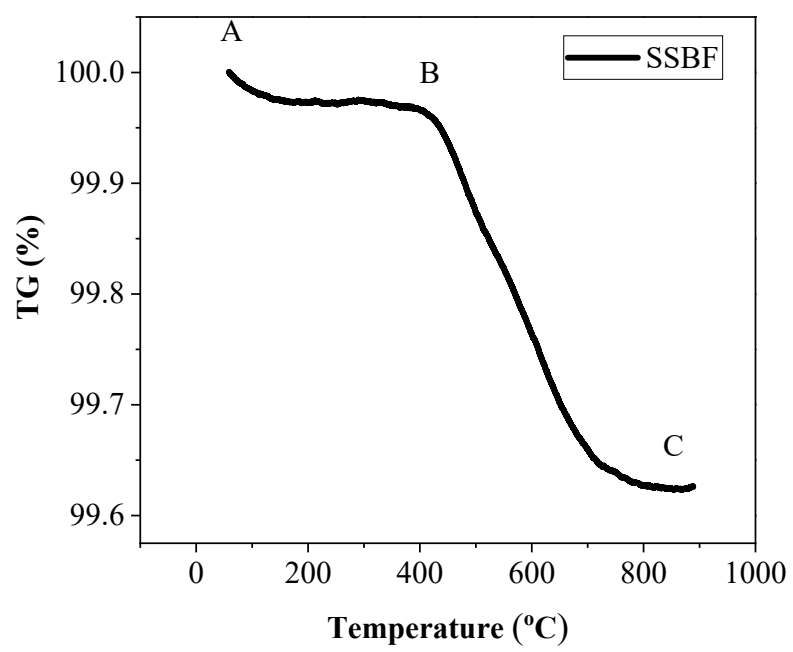

Fig. 2. Thermogravimetric analysis of the SSBF composite cathode powders
The thermal gravimetric analysis of the SSBF cathode material from room temperature to $1,000{ }^{\circ} \mathrm{C}$ is shown in Fig. 2. During the heating phase, the thermal gravimetric curve demonstrated the conduct of weight in percent TG. The curve began at $25^{\circ} \mathrm{C}$ and remained steady until it reached $150{ }^{\circ} \mathrm{C}$. At $380{ }^{\circ} \mathrm{C}$, the curve will continue to decrease until it reaches 0.03 percent TG (point $B$ to $C$ ). Finally, as the temperature reached $900{ }^{\circ} \mathrm{C}$, the curve dropped dramatically along points $C-D$, with a decrease of 0.17 percent TG.

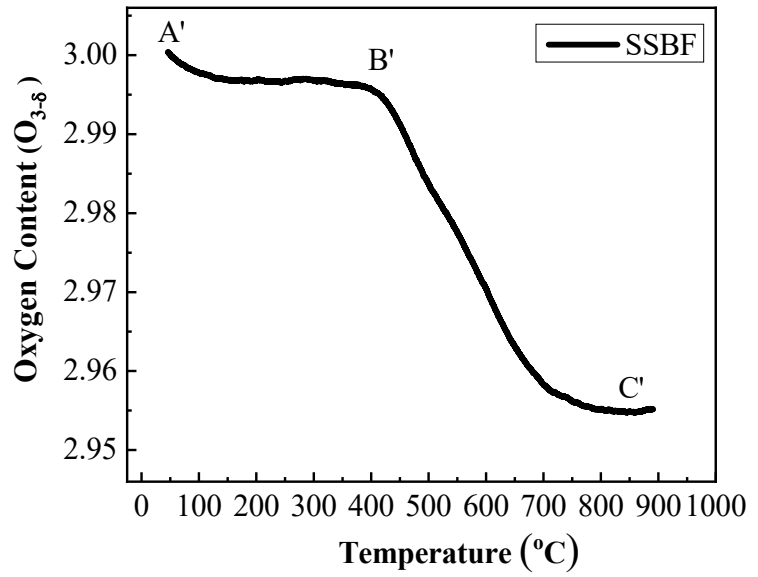

Fig. 3. Oxygen content of SSBF composite cathode powders

During the calcination process, the oxygen content in the SSBF composite material was monitored. The model's oxygen content was calculated using $\mathrm{O}_{3-\delta}$ in the perovskite structure. The curve slope was close to that of the TG study shown in Fig. 2. The stable curve was found in the $A^{\prime}$ to $B$ ' range. The decreasing curve of $0.02 \mathrm{O}_{3-\delta}$ was found at point $B^{\prime}$ to $C^{\prime}$.

\section{2. Structure characterization}

The XRD pattern of the composite SSBF structure (B) calcined at $1,000{ }^{\circ} \mathrm{C}$ for 4 hours and the perovskite structure (A) of lanthanum ferrite $\left(\mathrm{LaFeO}_{3}\right)$ as a reference is shown in Fig. 4.

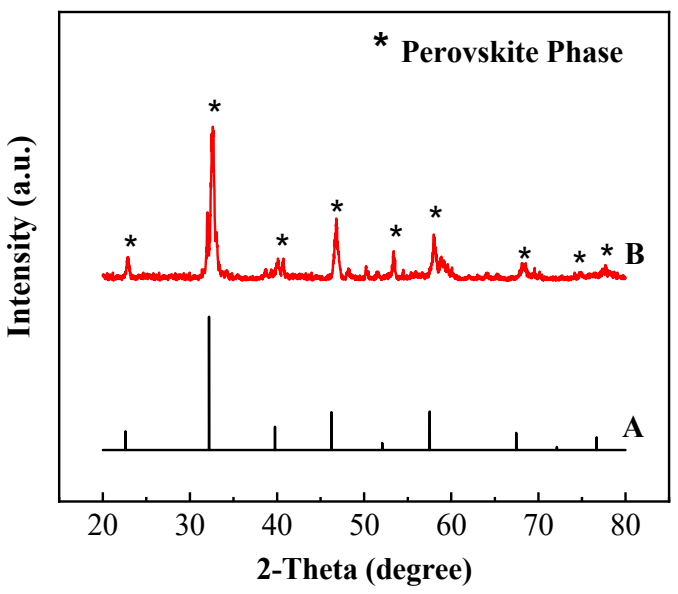

Fig. 4. SSBF cathode XRD diffraction pattern

The single phase of the SSBF structure is constructed on the composite model system. The sequence in Fig. 4 showed the peak's sharpness and narrowness in detail $(B)$. The 
pattern has nine major peaks with a scale of 60 degrees in 2-theta. $22.98^{\circ}, 32.74^{\circ}, 40.66^{\circ}, 46.88^{\circ}, 52.52^{\circ}, 57.98^{\circ}, 67.72^{\circ}$, $72.78^{\circ}$, and $77.44^{\circ}$ were the peak positions. Those peaks are similar to the perovskite structure references $(A)$.

\section{3. Electrical conductivity properties}

Fig. 5 displays the electrical conductivity curve for SSBF cathode composite products. The testing was carried out from $200 \equiv \mathrm{C}$ to $800{ }^{\circ} \mathrm{C}$ under atmospheric air pressure, with an oxygen concentration of $0.21 \mathrm{~atm}$ (21 percent $\mathrm{O}_{2}$ ).

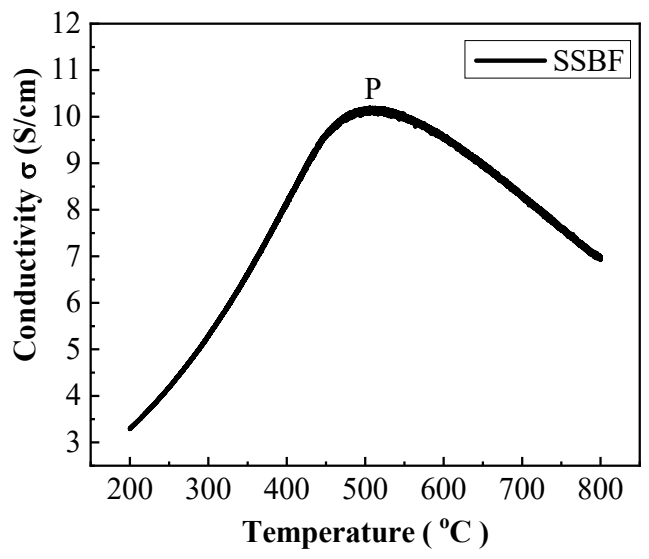

Fig. 5. SOFC cathode composite materials of electrical conductivity

The parabolic curve was visible in the conductivity value at the start of $3.25 \mathrm{~S} \mathrm{~cm}^{-1}$ at $200{ }^{\circ} \mathrm{C}$. The conductivity increases gradually as the temperature rises, peaking at $10.20 \mathrm{~S} \mathrm{~cm}^{-1}$ at $502{ }^{\circ} \mathrm{C}$ in point $P$, and decreasing simultaneously to $7.25 \mathrm{~S} \mathrm{~cm}^{-1}$ at $800{ }^{\circ} \mathrm{C}$.

\section{Discussion of experimental results on the design of solid oxide structure on the composite cathode for IT-SOFC}

The weight loss of composite material compound was analyzed in detail by the thermal gravimetric analysis. The decrease of the curve in the first step of TG shown in Fig. 1 occurred at $289{ }^{\circ} \mathrm{C}$ and $422^{\circ} \mathrm{C}$, which was attributed to the weight loss of SSBF powders. The first step was due to the heat energy provided by the device, the water in the SSBF powders could be evaporated. The other way, the samarium powder element was contributed by the weight loss in the temperature range [24], also showed the evaporated water quality. It was also shown by the endothermic peak at the same temperature caused by substance dehydration. The second step at $422^{\circ} \mathrm{C}$, the weight loss was thought to be dominated by evaporation due to samarium content impurity. Since strontium carbonate decomposes into SSBF oxide compounds, the rate of weight loss accelerates. The decreasing curve at the third step at point 4 started at $710{ }^{\circ} \mathrm{C}$ to $899{ }^{\circ} \mathrm{C}$ was initiated by some elements reacting to form the new structure in the system. In this step, the solid-state reaction mechanism was playing to form the perovskite structure. According to the TG analysis, the calcination temperature could be employed enough up to $1,000{ }^{\circ} \mathrm{C}$. The endothermic reaction will also demonstrate the formation of the perovskite matrix, as seen by XRD characterization in Fig. 4. Besides, the system's heat energy influences the decrease in oxygen content shown in Fig. 3. The reduction reaction for the perovskite structure in the SSBF cathode could be aided by heat energy as oxygen levels drop to 2.98 of $\mathrm{O}_{3-\delta}$. Unless the temperature rises, the volume of oxygen in the air decreases, making it possible to transfer mobility oxygen in the cathode system, which was used in the IT-SOFC system.

To better understand the crystalline structure formed, the XRD pattern for the SSBF cathode was shown in detail. Fig. 4 displays the XRD pattern of nine main peaks with different intensities at various theta positions relative to the crystalline structure (A). The perovskite phase was evident in the crystalline form on the composite model framework. The arrangement of the phase is also similar to that of a nearly cubic $\mathrm{LaFeO}_{3}$ structure in Fig. 4 (A) [10, 15], implying that the single perovskite phase crystalline structure is built on the SSBF cathode. The Sm, Ba and Sr components of the model system were used in the A-side of the model system, which was configured for the SSBF cathode materials in the perovskite phase. Based on the XRD pattern above, the stoichiometric structure of the composite metal oxide for the SSBF cathode materials could be developed as a crystalline structure with the single perovskite phase using the solid-state reaction process.

The conductivity performance demonstrated by the SSBF composite was the mix of the electronic and ionic conductivity, which was associated with the electronic hole and the oxygen vacancy in the structure. The increase in conductivity at lower temperatures is associated with the transfer of thermally activated electrons by jumping through $\mathrm{Fe}^{4+}-\mathrm{O}-\mathrm{Fe}^{3+}$. Whereas the decrease in conductivity above $498^{\circ} \mathrm{C}$ is related to the reduction of electronic hole concentration through thermal reduction of $\mathrm{Fe}^{4+}, \mathrm{Fe}^{3+}$, as well as the formation of more oxygen vacancies. This may be caused by the degradation of the electrostatic attractive force between anions $\left(\mathrm{O}^{2-}\right)$ and thermally reduced cations at high temperatures. Furthermore, because of the lack of oxygen in the SSBF cathode, the angle of the curves increases as the temperature rises. The thermal conductivity behavior was consistent with the oxygen content trend in the TG analysis for reducing weight of the SSBF composite. However, more characterization including thermal expansion testing and surface morphology is needed to investigate the SSBF composite in detail. Moreover, further studies will be carried out to develop the performance of SSBF for integrating in the electrolyte and cathode layers on the single cell system.

\section{Conclusions}

1. The weight loss on the SSBF composite model in the TG analysis was dominated by the elements decomposition process related to the solid-state reaction for constructing the new structure in the cobalt-free system.

2. The single phase associated with the perovskite structure was built on the SSBF composite system demonstrated in detail by the XRD results. The stoichiometric structure of the composite metal oxide for the SSBF cathode materials could be obtained as a crystalline structure with the single perovskite phase using the solid-state reaction method.

3. The compounding of $\mathrm{Ba}$ element to the $\mathrm{Sm}$ and $\mathrm{Sr}$ system in the A-side improved the electronic conductivity 
properties in the SSBF cathode systems. The metallic element led to the generation of the conductive behavior at the low temperature, while the ionic structure acted as elevated temperature. The SSBF composite material might well be promising as an alternative cathode for IT-SOFC based on these studies.

\section{Acknowledgments}

The author would like to acknowledge the funding support to this research from DIPA Politeknik Negeri Jakarta for Penelitian Dasar Unggulan Perguruan Tinggi No. B.264/PL3.B/PN.00.03/2021

\section{References}

1. Tan, L., Dong, X., Gong, Z., Wang, M. (2018). Analysis on energy ef fi ciency and $\mathrm{CO}_{2}$ emission reduction of an SOFC- based energy system served public buildings with large interior zones. Energy, 165, 1106-1118. doi: http://doi.org/10.1016/j.energy.2018.10.054

2. Naimaster, E. J., Sleiti, A. K. (2013). Potential of SOFC CHP systems for energy-efficient commercial buildings. Energy and Buildings, 61, 153-160. doi: http://doi.org/10.1016/j.enbuild.2012.09.045

3. Bompard, E., Napoli, R., Wan, B., Orsello, G. (2008). Economics evaluation of a 5kW SOFC power system for residential use. International Journal of Hydrogen Energy, 33 (12), 3243-3247. doi: http://doi.org/10.1016/j.ijhydene.2008.04.017

4. Fernandes, A., Woudstra, T., van Wijk, A., Verhoef, L., Aravind, P. V. (2016). Fuel cell electric vehicle as a power plant and SOFC as a natural gas reformer: An exergy analysis of different system designs. Applied Energy, 173, 13-28. doi: http://doi.org/10.1016/ j.apenergy.2016.03.107

5. Ramadhani, F., Hussain, M. A., Mokhlis, H., Hajimolana, S. (2017). Optimization strategies for Solid Oxide Fuel Cell (SOFC) application: A literature survey. Renewable and Sustainable Energy Reviews, 76, 460-484. doi: http://doi.org/10.1016/ j.rser.2017.03.052

6. Jiang, S., Sunarso, J., Zhou, W., Shen, J., Ran, R., Shao, Z. (2015). Cobalt-free $\operatorname{SrNbxFe}_{1-\mathrm{x}} \mathrm{O}_{3-\delta}(\mathrm{x}=0.05,0.1$ and 0.2$)$ perovskite cathodes for intermediate temperature solid oxide fuel cells. Journal of Power Sources, 298, 209-216. doi: http://doi.org/10.1016/ j.jpowsour.2015.08.063

7. Li, C.-H., Hu, S.-H., Tay, K.-W., Fu, Y.-P. (2012). Electrochemical characterization of gradient $\mathrm{Sm}_{0.5} \mathrm{Sr}_{0.5} \mathrm{CoO}_{3-\delta}$ cathodes on $\mathrm{Ce}_{0.8} \mathrm{Sm}_{0.2} \mathrm{O}_{1.9}$ electrolytes for solid oxide fuel cells. Ceramics International, 38 (2), 1557-1562. doi: http://doi.org/10.1016/ j.ceramint.2011.09.041

8. Wang, S., Feng, Y., Wang, D. (2014). Electrochemical comparison of cobalt-free $\mathrm{La}_{0.5} \mathrm{Sr} 0.5 \mathrm{Fe}_{0.9} \mathrm{Mo}_{0.1} \mathrm{O}_{3-\delta}$ based cathode materials for intermediate-temperature solid oxide fuel cells. Ceramics International, 40 (4), 6359-6363. doi: http://doi.org/10.1016/ j.ceramint.2013.10.133

9. Subardi, A., Chen, C.-C., Cheng, M.-H., Chang, W.-K., Fu, Y.-P. (2016). Electrical, thermal and electrochemical properties of $\mathrm{SmBa}_{1-\mathrm{x}} \mathrm{SrxCo}_{2} \mathrm{O}_{5+\delta}$ cathode materials for intermediate-temperature solid oxide fuel cells. Electrochimica Acta, 204, 118-127. doi: http://doi.org/10.1016/j.electacta.2016.04.069

10. Baharuddin, N. A., Muchtar, A., Somalu, M. R. (2017). Short review on cobalt-free cathodes for solid oxide fuel cells. International Journal of Hydrogen Energy, 42 (14), 9149-9155. doi: http://doi.org/10.1016/j.ijhydene.2016.04.097

11. Ling, Y., Zhao, L., Lin, B., Dong, Y., Zhang, X., Meng, G., Liu, X. (2010). Investigation of cobalt-free cathode material $\mathrm{Sm}_{0.5} \mathrm{Sr}_{0.5} \mathrm{Fe}_{0.8} \mathrm{Cu}_{0.2} \mathrm{O}_{3-\delta}$ for intermediate temperature solid oxide fuel cell. International Journal of Hydrogen Energy, 35 (13), 6905-6910. doi: http://doi.org/10.1016/j.ijhydene.2010.04.021

12. Liu, H., Zhu, K., Liu, Y., Li, W., Cai, L., Zhu, X. et. al. (2018). Structure and electrochemical properties of cobalt-free perovskite cathode materials for intermediate-temperature solid oxide fuel cells. Electrochimica Acta, 279, 224-230. doi: http://doi.org/ 10.1016/j.electacta.2018.05.086

13. Zhao, L., He, B., Zhang, X., Peng, R., Meng, G., Liu, X. (2010). Electrochemical performance of novel cobalt-free oxide $\mathrm{Ba}_{0.5} \mathrm{Sr}_{0.5} \mathrm{Fe}_{0.8} \mathrm{Cu}_{0.2} \mathrm{O}_{3-\delta}$ for solid oxide fuel cell cathode. Journal of Power Sources, 195 (7), 1859-1861. doi: http://doi.org/ 10.1016/j.jpowsour.2009.09.078

14. Pang, S., Wang, W., Chen, T., Shen, X., Wang, Y., Xu, K., Xi, X. (2016). Systematic evaluation of cobalt-free $\operatorname{Ln}_{0.5} \mathrm{Sr}_{0.5} \mathrm{Fe}_{0.8} \mathrm{Cu}_{0.2} \mathrm{O}_{3-\delta}$ $(\mathrm{Ln}=\mathrm{La}, \mathrm{Pr}$, and $\mathrm{Nd})$ as cathode materials for intermediate-temperature solid oxide fuel cells. Journal of Power Sources, 326, 176-181. doi: http://doi.org/10.1016/j.jpowsour.2016.06.134

15. Ding, X., Gao, X., Zhu, W., Wang, J., Jiang, J. (2014). Electrode redox properties of $\mathrm{Ba}_{1-\mathrm{x}} \mathrm{La}_{\mathrm{X}} \mathrm{FeO}_{3-\delta}$ as cobalt free cathode materials for intermediate- temperature SOFCs. International Journal of Hydrogen Energy, 39 (23), 12092-12100. doi: http://doi.org/ 10.1016/j.ijhydene.2014.06.009

16. Meng, X., Ll, S., Yu, W. W., Ji, Y., Sui, Y., Wei, M. (2018). Layered perovskite $\operatorname{LnBa}_{0.5} \mathrm{Sr}_{0.5} \mathrm{Cu}_{2} \mathrm{O}_{5+\delta}(\mathrm{Ln}=\operatorname{Pr}$ and Nd) as cobaltfree cathode materials for solid oxide fuel cells. International Journal of Hydrogen Energy, 43 (9), 4458-4470. doi: http://doi.org/ 10.1016/j.ijhydene.2018.01.033

17. Ling, Y., Zhang, X., Wang, Z., Wang, S., Zhao, L., Liu, X., Lin, B. (2013). Potentiality of cobalt-free perovskite $\mathrm{Ba}_{0.5} \mathrm{Sr}_{0.5} \mathrm{Fe}_{0.9} \mathrm{Mo}_{0.1} \mathrm{O}_{3-\delta}$ as a single-phase cathode for intermediate-to-low-temperature solid oxide fuel cells. International Journal of Hydrogen Energy, 38 (33), 14323-14328. doi: http://doi.org/10.1016/j.ijhydene.2013.08.089

18. Chen, D., Chen, C., Dong, F., Shao, Z., Ciucci, F. (2014). Cobalt-free polycrystalline $\mathrm{Ba}_{0.95} \mathrm{La}_{0.05} \mathrm{FeO}_{3-\delta}$ thin films as cathodes for intermediate-temperature solid oxide fuel cells. Journal of Power Sources, 250, 188-195. doi: http://doi.org/10.1016/ j.jpowsour.2013.11.010 
19. Fu, Y. P. (2010). $\mathrm{Sm}_{0.5} \mathrm{Sr}_{0.5} \mathrm{Co}_{0.4} \mathrm{Ni}_{0.6} \mathrm{O}_{3-8}-\mathrm{Sm}_{0.2} \mathrm{Ce}_{0.8} \mathrm{O}_{1.9}$ as a potential cathode for intermediate-temperature solid oxide fuel cells. International Journal of Hydrogen Energy, 35 (16), 8663-8669. doi: http://doi.org/10.1016/j.ijhydene.2010.05.109

20. Ding, X., Kong, X., Wu, H., Zhu, Y., Tang, J., and Zhong, Y. (2012). $\mathrm{SmBa}_{0.5} \mathrm{Sr}_{0.5} \mathrm{Cu}_{2} \mathrm{O}_{5+\delta}$ and $\mathrm{SmBa}_{0.5} \mathrm{Sr}_{0.5} \mathrm{CuFeO}_{5+\delta}$ layered perovskite oxides as cathodes for IT-SOFCs. International Journal of Hydrogen Energy, 37 (3), 2546-2551. doi: http://doi.org/ 10.1016/j.ijhydene.2011.10.080

21. Subardi, A., Chen, C. C., Cheng, M. H., Chang, W. K., Fu, Y. P. (2016). Electrical, thermal and electrochemical properties of $\mathrm{SmBa}_{1-\mathrm{x}} \mathrm{Sr}_{\mathrm{x}} \mathrm{Co}_{2} \mathrm{O}_{5+\delta}$ cathode materials for intermediate-temperature solid oxide fuel cells. Electrochimica Acta, 204, 118-127. doi: http://doi.org/10.1016/j.electacta.2016.04.069

22. Subardi, A., Liao, K. Y, Fu, Y. P. (2019). Oxygen transport, thermal and electrochemical properties of $\mathrm{NdBa}_{0.5} \mathrm{Sr}_{0.5} \mathrm{Co}_{2} \mathrm{O}_{5+\delta} \mathrm{cathode}$ for SOFCs, J. Eur. Ceram. Soc., 39(1), 30-40. doi: 10.1016/j.jeurceramsoc.2018.01.022

23. Subardi, A., Susanto, I., Kartikasari, R., Tugino, T., Kuntara, H., Wijaya, A. E. et. al. (2021). An analysis of $\mathrm{SmBa}_{0.5} \mathrm{Sr}_{0.5} \mathrm{CO}_{2} \mathrm{O}_{5+\delta}$ double perovskite oxide for intermediate-temperature solid oxide fuel cells," Eastern-European Journal of Enterprise Technologies, 2 (12 (110)), 6-14. doi: http://doi.org/10.15587/1729-4061.2021.226342

24. Susanto, I., Kamal, D. M., Ruswanto, S., Subarkah, R., Zainuri, F., Permana, S. et. al. (2020). Development of cobalt-free oxide $\left(\mathrm{Sm}_{0.5} \mathrm{Sr}_{0.5} \mathrm{Fe}_{0.8} \mathrm{Cr}_{0.2} \mathrm{O}_{3-\delta}\right)$ cathode for intermediate-temperature solid oxide fuel cells (IT-SOFCs). Eastern-European Journal of Enterprise Technologies, 6 (5 (108)), 15-20. doi: http://doi.org/10.15587/1729-4061.2020.217282 